\title{
CCNA1 Gene
}

National Cancer Institute

\section{Source}

National Cancer Institute. CCNA1 Gene. NCI Thesaurus. Code C104227.

This gene is involved in cell cycle regulation. 